\title{
Fixation and Fixatives: Roles and Functions-A Short Review
}

\author{
Himanshu Singh ${ }^{1} \quad$ Kundendu Arya Bishen ${ }^{1}$ Deepti Garg ${ }^{2}$ Hemani Sukhija ${ }^{1}$ Dheeraj Sharma \\ Urvashi Tomar ${ }^{1}$
}

\author{
${ }^{1}$ Department of Oral and Maxillofacial Pathology, Index Institute of \\ Dental Sciences, Malwanchal University, Indore, Madhya Pradesh, India \\ 2Department of Oral and Maxillofacial Pathology, Bhojia Dental \\ College, Baddi, Himachal Pradesh, India
}

\begin{abstract}
Address for correspondence Kundendu Arya Bishen, MDS, PhD Department of Oral and Maxillofacial Pathology, Index Institute of Dental Sciences, Malwanchal University, Indore 452016, Madhya Pradesh, India (e-mail: kundenduarya@gmail.com).
\end{abstract}
Abstract
Keywords
- fixatives
- fixation
- formaldehyde
- glutaraldehyde
- glyoxal
- osmium tetroxide
- picric acid

Fixation is considered as physiochemical process where cells or tissues are fixed chemically. Fixatives perform various functions such as prevention of autolysis and tissue putrefaction. Various fixative agents include formaldehyde, glutaraldehyde, osmium tetroxide, glyoxal, picric acid, and so on. A detailed search on PubMed, Google scholar, and Scopus database showed very few articles on "fixation" and "fixative." Keeping this fact in mind, a comprehensive review on fixation and fixatives was prepared. The main aim of this review is to make pathologists and laboratory technicians familiar with the basic aspects and different types of fixatives.

\section{Introduction}

Fixation is known as a physiochemical process in which cells or tissues are fixed chemically. As a result, the tissue or cell can combat the successive treatment by different reagents with negligible disfigurement of morphology. ${ }^{1}$

An ideal fixation involves complicated progression of chemical episodes. An ideal fixative is presumed to transmit mechanical toughness to tissue so that it resists destruction due to further processing steps. It prevents the autolysis, putrefaction of tissue as well as tissue component degradation. ${ }^{1,2}$ Fixation should be able to preserve the cellular structure and tissue architecture in life-like manner. ${ }^{2}$

For the purpose of tissue processing in the histopathology, fixation of tissue is considered as necessary and essential step. Fixation amends the physio-chemical state of tissues so that it remodels the reactiveness of cellular components for stains. ${ }^{3}$ Fixatives can be classified in different ways, as shown in - Tables 1 - 3 .

\section{Functions of Fixative}

Fixatives perform various functions. The primary function of fixatives is to prevent autolysis (enzymes attack) as well

received

April 6, 2019

accepted

May 20, 2019

published online

August 29, 2019

as putrefaction (bacterial attack) of tissues. Autolysis seems to be a frequent issue in enzyme-rich tissues, and rigorously autolyzed tissue does not get stained properly for microscopic examination. On the other hand, bacterial invasion can be blocked by following the strict antiseptic methods.

Another important function is conserving the association in between cells and extracellular substances. Fixatives stabilize the cell component by making them insoluble, thereby reducing the alteration by subsequent treatment and also preventing osmotic damage of tissue, which may cause shrinkage or swelling, thus preserving the cellular and tissue structure in life-like state.

Fixation also performs various other functions such as making tissue firm, so that gross cutting becomes much easier. Also, fixatives help make the tissue more easily permeable for subsequent reagents and play a role in emphasizing the dissimilarity in refractive index and thus help in increased visibility of different elements of tissue..$^{1,2,4}$

\section{Factors Affecting Fixation and Fixatives}

\section{Length of Fixation}

The ideal time of fixation is experimentally determined for different types of tissue. If time period for fixation is longer,

License terms

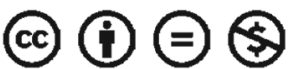


Table 1 Classification of fixatives based on chemical composition

\begin{tabular}{|c|l|l|}
\hline & Fixatives & Examples \\
\hline 1. & Physical agents & Heat, microwaves \\
\hline 2. & Aldehydes & $\begin{array}{l}\text { Formaldehyde, acrolein, } \\
\text { glutaraldehyde }\end{array}$ \\
\hline 3. & Coagulants & $\begin{array}{l}\text { Methyl alcohol, ethyl alcohol, } \\
\text { acetic acid }\end{array}$ \\
\hline 4. & Oxidizing agents & Osmium tetroxide \\
\hline 5. & Miscellaneous & Picric acid, mercuric chloride \\
\hline
\end{tabular}

Table 2 Classification of fixatives based on number of structures fixed

\begin{tabular}{|c|l|l|}
\hline & Fixatives & Examples \\
\hline 1. & Simple fixatives & $\begin{array}{l}\text { e.g., Formaldehyde, picric acid, } \\
\text { osmium tetroxide }\end{array}$ \\
\hline 2. & Compound fixatives & $\begin{array}{l}\text { e.g., Bouin's fluid, formol saline, } \\
\text { Zenker's fluid }\end{array}$ \\
\hline
\end{tabular}

Table 3 Classification of fixatives based on type of structures fixed

\begin{tabular}{|c|l|l|}
\hline & Fixatives & Examples \\
\hline 1. & $\begin{array}{l}\text { Histochemical } \\
\text { fixatives }\end{array}$ & $\begin{array}{l}\text { Formaldehyde, glutaraldehyde, vapor } \\
\text { fixatives }\end{array}$ \\
\hline 2. & $\begin{array}{l}\text { Microanatom- } \\
\text { ical fixatives }\end{array}$ & $\begin{array}{l}\text { Bouin's fluid, 10\% formalin, Zenker's } \\
\text { fluid, formol calcium, Heidenhain's } \\
\text { susa, Helly's fluid, Rossman's fluid, }\end{array}$ \\
\hline 3. & $\begin{array}{l}\text { Cytologic } \\
\text { fixatives }\end{array}$ & $\begin{array}{l}\text { Champy's fluid, glacial acetic acid, } \\
\text { alcohol, formol saline, Carnoy's fluid, } \\
\text { Clarke's fluid, Newcomer's fluid, } \\
\text { Flemming's fluid }\end{array}$ \\
\hline
\end{tabular}

it results in over-cross-linking, and samples become brittle. If time period for fixation is short, sufficient amount of penetration in tissues and cross-linking will not occur. ${ }^{4}$ For oral soft tissue, overnight fixation is sufficient.

\section{Temperature}

Temperature of fixative during fixation may affect the tissue architecture. Rate of fixation is increased with increase in temperature, but increased temperature will also increase autolysis rate. If temperature is low or decreased, the diffusion rate also decreases, which results in extended penetration time. ${ }^{5}$ For electron microscopic studies, $0^{\circ}$ to $4^{\circ} \mathrm{C}$ is appraise as ideal temperature.

\section{Concentration}

Fixative agents need prolonged time for fixation if concentration is low. If concentrations of fixing agent are high, it results in damaging of cellular structures as well as obliterated enzyme activities. ${ }^{6}$ Different fixatives have different ideal concentration that is determined experimentally; for example, ideal fixative for oral soft tissue is formalin used in $10 \%$ concentrated solution.

\section{Size}

Tissue thickness is one of the important factors for fixation. If the sample size is large, it is unfavorable for the fixative to penetrate and reach to the deeper part of the tissue, which would result in autolysis of epithelium. ${ }^{4}$ Ideally 4 - to 6 -mm-thick specimen is best suited for complete penetration by fixatives.

\section{Osmolarity}

If osmolarity of tissue as well as fixative is same, it will prevent swelling or shrinkage of the tissue. ${ }^{7}$

\section{Various Fixating Agents Used in Histopathology}

\section{Formaldehyde or Formalin}

Formaldehyde was discovered in 1859 by Butlerov. In 1889 Ttrillat was the first who manufactured formaldehyde commercially as industrial reagent. In 1892, Ferdinand Blum recognized that formalin could give benefit when used as a fixative. ${ }^{8,9}$

The most routinely used solution for fixation of tissue $-10 \%$ formalin solution $\mathrm{v} / \mathrm{v}-$ is nothing but an aqueous suspension of formaldehyde In 10\% neutral buffered form, formaldehyde is found to be the most commonly used fixative in pathology. Reaction between the formaldehyde and macromolecules of tissue seems to be complex. Formaldehyde reacts with nucleic acids as well as proteins, and it penetrates between nucleic acids and proteins and forms stabilized shell of nucleic acid-protein complex. ${ }^{10-13}$ As compared with other fixatives, formaldehyde causes lesser tissue shrinkage, with exceptions being acetone and ethanol. Formaldehyde seems to harden tissue more when compared with other fixatives. The lipids are conserved, but carbohydrates are not fixed by formaldehyde. ${ }^{4}$

Formalin comprises 37 to $40 \%$ formaldehyde and 60 to $63 \%$ water by weight. After continuous storage for long periods, accumulations of white deposits are observed in the solution. These are the precipitates of paraformaldehyde. By storing formalin at low temperature, these white deposits can be avoided. Also, 10\% methanol may be added into the formalin to minimize the polymerization reaction that produces paraformaldehyde precipitate. It also contains a slight amount of formate ions. These are obtained from Cannizzaro reaction. In this reaction, two molecules of formaldehyde react together. One molecule condenses to form methanol and second molecule gets oxidized to form formic acid. ${ }^{14}$ The solution is acidic in reaction because of formic acid, but acidic nature of solution can be counterbalanced with incorporation of magnesium carbonate in little proportion. ${ }^{15}$

\section{Glutaraldehyde}

Glutaraldehyde was found in 1963 by Sabatini et al as particular fixative for ultrastructural researches. Glutaraldehyde comprises two aldehyde groups that are divided by three methylene bridges. Although penetration rate of glutaraldehyde is found to be slower when compared with formaldehyde, 
glutaraldehyde is more effective cross-linker for proteins than formaldehyde and it also inhibits enzyme activity. ${ }^{16-18}$

When polymerization of aqueous solution of glutaraldehyde occurs, it forms oligomeric and cyclic compounds, and also forms glutaric acid by oxidation. For stability, it requires $\mathrm{pH}$ of 5 and storage at $4^{\circ} \mathrm{C} .{ }^{19,20}$ At room temperature, glutaraldehydes are not able to cross-link the nucleic acids. ${ }^{21}$

Glutaraldehyde preserves the ultrastructure of the tissue, thereby it is used in electron microscopy studies, but owing to poor penetration and overhardening properties, it is not used as tissue fixatives for light microscopy. On exposure to oxygen, glutaraldehyde becomes unstable and breaks down with decrease in pH. Glutaraldehyde can act as sensitizer, and its exposure may result in respiratory tract, skin, and digestive tract irritation. ${ }^{4}$

\section{Osmium Tetroxide}

Osmium tetroxide is type of fixative that is water soluble and also soluble in nonpolar solvents. Osmium tetroxide seems to react with proteins side chains that cause cross-linking. The reactive groups of osmium tetroxide include various groups such as disulfide, carboxyl, hydroxyl, sulfydryl, amide, and so on. ${ }^{22}$ During fixation by osmium tetroxide, either due to slow rate of reaction or due to restricted penetration of osmium tetroxide into tissue, large amounts of carbohydrates as well as proteins are eradicated.

For electron microscopic studies, osmium tetroxide is used as secondary fixative, and it also performs well as stain and imparts contrast when observed under electron microscope. Osmium tetroxide is also helpful for staining of lipids in frozen sections. It is observed that fixation by osmium tetroxide causes swelling in tissue, which can be decreased by adding sodium chloride or calcium chloride to fixatives. ${ }^{21}$

It is traditionally sold as crystalline solid that is sealed in glass ampule. It is seen that osmium tetroxide crystals convert from solid state to vapor state. Continued exposure to osmium tetroxide vapors can cause deposition into cornea, which eventually leads to blindness. ${ }^{23,24}$

\section{Mercuric Chloride}

Mercuric chloride can also be used as a tissue fixative for histopathology. It chiefly reacts with cysteine and also reacts with amines, amides, sulfydryl groups, and ammonium salts, and results in tissue hardness. It acts as a strong protein coagulant.

With acid dyes, it shows strong staining affinity. It also reacts with phosphate remnants of nucleic acids and adequately fixes the nucleoproteins. Therefore, because of these reasons, it is observed that mercuric fixatives are the major component of some fixatives such as Helly's fixative and b-5 fixatives. ${ }^{4,18}$

Nowadays, mercurial fixatives are not routinely used except for fixation of hematopoietic tissues. Mercury-based fixatives show some characteristics features. They are toxic in nature and should not be allowed to come in contact with metals. These fixatives have slow penetration capacity, so the thickness of the specimens being fixed by mercuric fixatives should be thin. ${ }^{25}$

\section{Glyoxal}

Glyoxal was first advocated in 1943. They are also known as ethanedial or oxalaldehyde. Glyoxal is considered as alternative fixative to formalin because it is a dialdehyde in nature. It is a bifunctional aldehyde. Its individual aldehyde groups are potentially reactive, and also cross-links can be established. Glyoxal fixed tissues may demonstrate precise cellular details, lysed erythrocytes, and disintegrated microcalcifications. ${ }^{26-28}$

According to Harke and Hoffler, glyoxal does not evaporate from the solution, and as per Henry law constant, glyoxal is virtually nonvolatile with consideration to the aqueous phase. For microwave fixation, glyoxal is the chief component used in the fixatives. It does not produce vapors at room temperature, so it is considered as less dangerous in use than formaldehyde. ${ }^{29}$ By molecular weight, glyoxal is the third smallest aldehyde after formaldehyde and acetaldehyde. It contains two carbon atoms. Glyoxal is commercially manufactured as aqueous solution that contains hydrates such as trimers, dimmers, and ring strucutres..$^{30}$

\section{Picric Acid}

Picric acid is an example of a coagulant fixative. It forms picrates with basic protein groups, which causes coagulation. For the purpose of demonstration of DNA or RNA, picric acid fixatives are not used as picric acid and can hydrolyze nucleic acids. Also, picric acid is seen to disintegrate calcium deposits in samples. Although picric acid is not able to fix most carbohydrates and lipids, picric acid is the most advised fixative to preserve glycogen. Brighter staining is seen by picric acid fixatives. ${ }^{4,18,31}$

Picric acid is an acidic solution. Therefore, sometimes it gets washed out by alcohol. To avoid this, lithium carbonate is added, which acts as a neutralizer. Luna reported that if picric acid is present in the tissue or not completely removed, distortion or obliteration of cellular structures will occur as outcome. .,32 $^{2}$

\section{Ethanol and Methanol}

For ethanol and methanol, fixation initiates at 50 to $60 \%$ concentration and greater than $80 \%$ concentration, respectively. They are known to be coagulants that cause protein denaturation. They cause interruption in hydrogen and hydrophobic bonding by substituting water in tissue environment, which results in change in tertiary structure.

Ethanol causes mispresentation of cytoplasmic as well as nuclear details, but sometimes it can be used for preservation of glycogen. Methanol is more commonly used for fixation of exfoliative cytology smears and blood films. ${ }^{18,33,34}$

\section{Acetone}

Acetone is another fixative agent used in histopathology. It acts as an efficacious lipid solvent that results in tissue brittleness. Apart from tissue fixation, they are primarily used as an agent for dehydration in tissue processing. Because of extremely volatile as well as flammable nature, they are not recommended for use in automatic tissue processor. ${ }^{18,33}$ 


\section{Acetic Acid}

Acetic acid is considered as a noncoagulative fixative agent. It acts by causing nuclear proteins coagulation. Incidentally, it stabilizes and assists to prevent nucleic acids loss. Acetic acid, when combined with ethanol, is used as an effective cytological fixative that helps in conservation of nucleic acids, but if it is used singly, it results in swelling of cells. Time required for fixation by acetic acid is less as penetration of acetic acid is faster into tissues. ${ }^{35}$

\section{Potassium Dichromate}

Potassium dichromate is also a noncoagulant fixative, but if used in combination with acid solution, it acts as a coagulant fixative. It is seldom used alone for fixation because chromate ions will link with few lipids and makes them insoluble.

Chromium seems to react with hydroxyl as well as carboxyl groups. By increasing the amount of reactive basic groups, the affinity of tissues for eosin staining will boost up. It conserves mitochondria but dissolves DNA. It is suggested that tissues that are fixed with chromate fixatives have to be washed completely in water before processing of tissues any further. This step is important as it avoids establishment of chromate suboxide that is insoluble. ${ }^{4,18}$

\section{Bouin's Fixative}

Bouin's fixative is known as noncoagulant picrate fixative solution and was explained by Pol Andre Bouin in 1897. Bouin's fixative is considered as good fixative for conserving delicate as well as soft tissue structures. The major portion of Bouin's fixative contains picric acid with little quantity of acetic acid as well as formaldehyde. In the samples that have to be undertaken in situ hybridization, Bouin's solution cannot be used because it decreases the severity of hybridization. ${ }^{36-38}$

\section{Acrolein}

Acrolein was introduced by Luft as a primary fixative agent, and it is a three carbon $\alpha \beta$ unsaturated monoaldehyde. Acrolein provides magnificent preservation of structural detail and conserves the virus antigenicity. ${ }^{16,39,40}$ It is also known as acrylic aldehyde. It reacts with macromolecules that result in formation of cross-links that are reversible.

Acrolein is not commonly used because it is unstable at alkaline $\mathrm{pH}$ and forms insoluble polymers. Acrolein is highly reactive and is found to penetrate tissues rapidly. Acrolein fixatives are chiefly used in enzyme histochemistry. ${ }^{2,18,33}$

\section{Genipin}

Genipin is a glycone derivative and is outcome of geniposide. Genipin is considered as a cross-linking agent used for biological tissue fixation. It initiates the cross-linking of free amino groups simultaneously with hydroxylysine and lysine. ${ }^{41,42}$ Genipin reacts with amino acids and results in formation of dark blue color pigment. The tissue resistance against collagenase degradation rises after tissue is fixed with genipin. It has been observed that genipin acts by forming intra- and intermolecular cross-linking with cyclic structure inside the collagen in tissues. ${ }^{43,44}$
Genipin is available as a crystalline white powder that is soluble in acetone, methanol, and ethanol. Genipin demonstrates its cross-linking properties at $\mathrm{pH}$ 7.4-8.5. ${ }^{43,44}$ It is a known cross-linking agent and has proved its potential in various biomedical application such as dentistry, articular cartilage tissue engineering applications, nerve regeneration, and so on..$^{45-47}$

\section{Conclusion}

Fixation is considered as key step in histopathology procedure. Each and every fixative has its own advantage and disadvantage. Various different fixatives perform various functions, and various factors such as size, temperature, and osmolarity have direct effect on fixation procedure.

\section{Note}

Prior to this publication, this study was not presented at any conference or convention.

\section{Funding}

None.

\section{Conflict of Interest}

None declared.

\section{References}

1 Bancroft JD, Gamble M, Theory and Practice of Histological Techniques. 5th ed. Philadelphia, PA: Churchill Livingstone Elsevier; 2002;63-108

2 Culling CFA, A Handbook of Histopathological and Histochemical Techniques. 4th ed. London: Butterworth Publication; 1985:27-77

3 Hayat MA, Stains and Cytochemical Methods. New York, NY; London, UK: Plenum Press;1993

4 Freida L, Carson CHC. Histotechnology: A Self Instructional Text. 3rd ed. American Society for Clinical Pathology Press, Hong Kong

5 Hornickel I, Kacza J, Schnapper A, et al. Demonstration of substances of innate immunity in the esophagus epithelium of domesticated mammals. Part I-methods and comparative fixation evaluation. Acta Histochem 2011;113(2):175-188

6 Thornthwaite JT, Thomas RA, Leif SB, et al. The use of electronic cell volume analysis with the AMAC II to determine the optimum glutaraldehyde fixative concentration for nucleated mammalian cells. Scan Electron Microsc 1978;2:1123

7 Guy Orchard, Brian Nation. Histopathology. 2nd ed. London: Oxford University Press;2018

8 Titford ME, Horenstein MG. Histomorphologic assessment of formalin substitute fixatives for diagnostic surgical pathology. Arch Pathol Lab Med 2005;129(4):502-506

9 Fox CH, Johnson FB, Whiting J, Roller PP. Formaldehyde fixation. J Histochem Cytochem 1985;33(8):845-853

10 French D, Edsall JT. The reactions of formaldehyde with amino acids and proteins. Adv Pro Cherlz 1945;2:277-335

11 McGhee JD, von Hippel PH. Formaldehyde as a probe of DNA structure. I. Reaction with exocyclic amino groups of DNA bases. Biochemistry 1975;14(6):1281-1296

12 McGhee JD, von Hippel PH. Formaldehyde as a probe of DNA structure. II. Reaction with endocyclic imino groups of DNA bases. Biochemistry 1975;14(6):1297-1303 
13 Chang YT, Loew GH. Reaction mechanisms of formaldehyde with endocyclic imino groups of nucleic acid bases. J Am Chem Soc 1994;116(8):3548-3555

14 Walker JF, Formaldehyde. 3rd ed. American Chemical Society Monograph Series. New York NY: Reinhold Publishing;1964

15 Baker FJ, Silverstone RE, Introduction to Medical Laboratory Technology. 5th ed. Butterworth-Heinemann;1976

16 Sabatini DD, Bensch K, Barrnett RJ. Cytochemistry and electron microscopy. The preservation of cellular ultrastructure and enzymatic activity by aldehyde fixation. J Cell Biol $1963 ; 17: 19-58$

17 Hopwood D. Some aspects of fixation with glutaraldehyde. A biochemical and histochemical comparison of the effects of formaldehyde and glutaraldehyde fixation on various enzymes and glycogen, with a note on penetration of glutaraldehyde into liver. J Anat 1967;101(Pt 1):83-92

18 Eltoum IE, Freenburgh J, Myers RB, Grizzle WE. Introduction to the theory and practice of fixation of tissues. J Histotechnol 2001;24(3):173-190

19 Hopwood D. Cell and tissue fixation, 1972-1 982. Histochern J 1985; 17(4):389-442

20 Hopwood D. Fixatives and fixation: a review. Histochem J 1969;1(4):323-360

21 Hayat MA, Principles and Techniques of Electron Microscopy. Biological Applications. 2nd ed, Vol. 1: Baltimore, MD: University Park Press; 1981

22 Hopwood D, Milne G, Penston J. A comparison of microwaves and heat alone in the preparation of tissue for electron microscopy. Histochem J 1990;22(6-7):358-364

23 Hayat MA, Fixation for Electron Microscopy. New York, NY: Academic Press; 1981

24 Glauert AM, Lewis PR, Biological Specimen Preparation for Transmission Electron Microscopy. Princeton, NJ: Princeton University Press; 1998

25 Hopwood D. Fixation with mercury salts. Acta Histochem Suppl 1973;13(0):107-118

26 Wicks LF, Suntzeff V. Glyoxal, a non-irritating aldehyde suggested as substitute for formalin in histological fixations. Science 1943;982539:204

27 Harke HP, Höffler J. Übergang antimikrobieller Wirkstoffe von der Fläche in die Luft. Hyg Med 1984;9:259-260

28 Betterton EA, Hoffmann MR. Henry's law constants of some environmentally important aldehydes. Environ Sci Technol 1988;22(12):1415-1418

29 Eltoum I, Fredenburgh J, Grizzle WE. Advanced concepts in fixation: 1. Effects of fixation on immunohistochemistry, reversibility of fixation and recovery of proteins, nucleic acids, and other molecules from fixed and processed tissues. 2. Developmental methods of fixation. J Histotechnol 2001;24(3):201-210

30 Anon., Glyoxal: A Technical Brochure. Wayne, NJ: American Cyanamid Company; $1986 ; 50$
31 Carleton HM, Drury RAB, Wallington EA, Carleton's Histological Technique. 5th ed. New York, NY: Oxford University Press; 1980

32 Luna LG, Histopathologic Methods and Color Atlas of Special Stains and Tissue Artifacts. Gaithersburg, MD: American Histolabs; 1992

33 Leong AS-Y, Fixation and fixatives. In: Woods AE, Ellis RC, eds. Laboratory Histopathology. New York, NY: Churchill Livingstone; 1994

34 Lillie RD, Fullmer HM, Histopathologic Technique and Practical Histochemistry. 4th ed. New York, NY: McGraw-Hill;1976

35 O'Brien TP, McCully ME, The Study of Plant Structure: Principles and Selected Methods. 1st ed. Melbourne, Australia: Termarcarphi;1981

36 Ortiz-Hidalgo C. Pol André Bouin, MD (1870-1962). Bouin's fixative and other contributions to medicine. Arch Pathol Lab Med 1992;116(8):882-884

37 Ananthanarayanan V, Pins MR, Meyer RE, Gann PH. Immunohistochemical assays in prostatic biopsies processed in Bouin's fixative. J Clin Pathol 2005;58(3):322-324

38 Nuovo GJ, Situ hybridization. In: Damjanov I, Linder J, eds. Anderson's Pathology. 10th ed. Maryland Heights, MO: Mosby; 1996

39 Luft JH. The use of acrolein as a fixative for light and electron microscopy. Anat Rec 1959;133:305

40 Mayor HD, Jordan LE. Acrolein-a fine structure fixative for viral cytochemistry. J Cell Biol 1963;18(1):207-213

41 Sung HW, Liang IL, Chen CN, Huang RN, Liang HF. Stability of a biological tissue fixed with a naturally occurring crosslinking agent (genipin) J Biomed Mater Res 2001;55(4):538-546

42 Sung HW, Huang RN, Huang LL, Tsai CC. In vitro evaluation of cytotoxicity of a naturally occurring cross-linking reagent for biological tissue fixation. J Biomater Sci Polym Ed 1999;10(1):63-78

43 Nishi C, Nakajima N, Ikada Y. In vitro evaluation of cytotoxicity of diepoxy compounds used for biomaterial modification. J Biomed Mater Res 1995;29(7):829-834

44 Sung HW, Chang Y, Liang IL, Chang WH, Chen YC. Fixation of biological tissues with a naturally occurring crosslinking agent: fixation rate and effects of $\mathrm{pH}$, temperature, and initial fixative concentration. J Biomed Mater Res 2000;52(1):77-87

45 Bedran-Russo AK, Pereira PN, Duarte WR. Drummond JL, Yamauchi M. Application of crosslinkers to dentin collagen enhances the ultimate tensile strength. J Biomed Mater Res B Appl Biomater 2007;80(1):268-272

46 Yan LP, Wang YJ, Ren L, et al. Genipin-cross-linked collagen/chitosan biomimetic scaffolds for articular cartilage tissue engineering applications. J Biomed Mater Res A 2010;95(2):465-475

47 Chiono V, Pulieri E, Vozzi G, Ciardelli G, Ahluwalia A, Giusti P. Genipin-crosslinked chitosan/gelatin blends for biomedical applications. J Mater Sci Mater Med 2008;19(2):889-898 